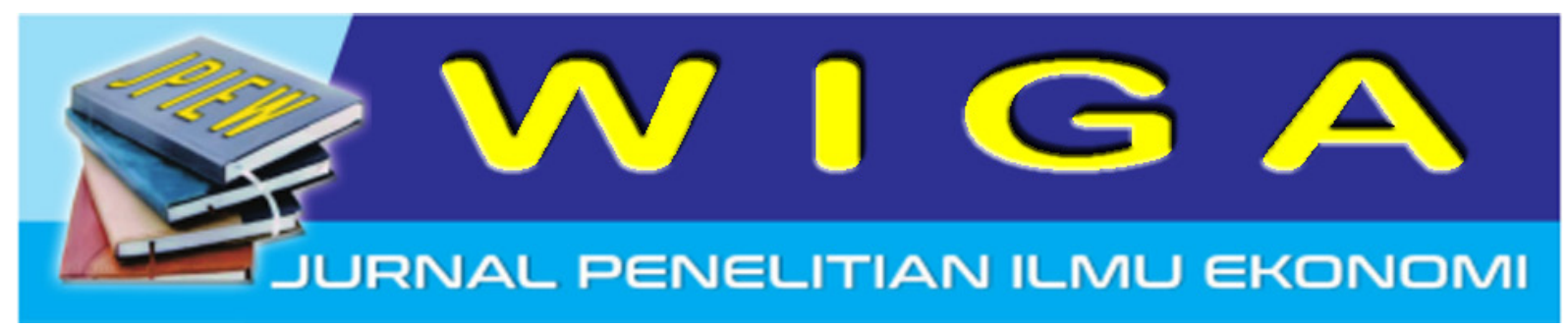

\title{
UPAYA PENGEMBANGAN TAMAN MONYET SEBAGAI ASSET PEMERINTAH BANDAR LAMPUNG
}

\author{
Rieka Ramadhaniyah $^{1}$, Herlina $^{2}$ \\ IIB Darmajaya Labuhan Ratu Kedaton Bandar Lampung \\ rramadhaniyah@yahoo.co.id ${ }^{1}$, herlina.anin.lavina@gmail.com²
}

\begin{abstract}
ABSTRAK
Tujuan penelitian ini adalah untuk memberikan kontribusi dalam melakukan upaya menarik turis domestik maupun mancanegara untuk mengunjungi hutan taman monyet yang cukup potensial sebagai objek pariwisata, menciptakan lapangan pekerjaan serta mengurangi tingkat penganguran di daerah tersebut. Meningkatkan pendapatan daerah Lampung terutama pemerintah kota Bandar Lampung dalam sektor pariwisata. Populasi dalam penenlitian adalah masyarakat Bandar lampung dengan sampel berjumlah 400 responden.
\end{abstract}

Hipotesis 1, 4, 5, 6 dan 7 adalah $\mathrm{H}_{\mathrm{O}}$ diterima artinya semua tidak mempunyai pengaruh signifikan, sedangkan untuk hipotesis 2 dan 3 adalah $\mathrm{H}_{\mathrm{a}}$ diterima artinya semua ada pengaruh signifikan. Hasil koefisien determinasi R Square sebesar 0,014 atau 14\%, hal ini menunjukkan bahwa bahwa variable aspek-aspek pengembangan pariwisata $\left(\mathrm{X}_{2}\right)$ dipengaruhi oleh variabel konsep pengembangan pariwisata dengan $\left(\mathrm{X}_{1}\right)$ sedangkan sisanya sebesar $81,6 \%$ dipengaruhi oleh faktor lain.

hal ini menunjukkan bahwa variabel asset pemerintah Bandar Lampung ( $\left.\mathrm{Y}_{2}\right)$ dipengaruhi oleh variabel konsep pengembangan pariwisata dengan ( $\left.\mathrm{X}_{2}\right)$ dan upaya pengembangan pariwisata $\left(\mathrm{Y}_{1}\right)$ dengan nilai persentase yang diperoleh sebesar 54,9\% sedangkan sisanya sebesar 36,1\% dipengaruhi oleh faktor lain selain variabel aspek - aspek pengembangan pariwisata (X2) dan upaya pengembangan pariwisata $\left(\mathrm{Y}_{1}\right)$.

Kata Kunci: Konsep pengambangan pariwisata, Upaya pengembangan pariwisata, Aspek-aspek pengembangan pariwisata, Asset Pemerintah.

\section{ABSTRACT}

The purpose of this research is to contribute in the efforts to attract domestic and foreign tourists to visit the monkey park forest of considerable potential as a tourist attraction, create jobs and reduce theunemployment rate in the area. Raising revenue Lampung Bandar Lampung city government especially 
in the tourism sector. Population in Bandar Lampung penenlitian is a community with a sample of 400 respondents.Hypothesis 1, 4, 5, 6 and 7 are Ho accepted means all has no significant effect, while for hypothesis 2 and 3 is $\mathrm{Ha}$ accepted means all there is significant influence. result the coefficient of determination $R$ Square of 0.014 or $14 \%$, this indicates that that variable aspects of tourism development (X2) is affected by the tourism development concept variables (X1) while the remaining $81.6 \%$ influenced by other factors. this suggests that government asset variable Bandar Lampung (Y2) is affected by the tourism development concept variables (X2) and tourism development efforts (Y1) with a percentage value obtained was $54.9 \%$ while the remaining $36.1 \%$ influenced by other factors in addition to the variable aspects - aspects of tourism development (X2) and tourism development efforts (Y1).

Keywords: floating concept of tourism, tourism development efforts, aspects of tourism development, the Government Asset.

\section{PENDAHULUAN}

Sektor kepariwisataan merupakan sumber devisa yang cukup besar persentase dan kontribusinya bagi kas daerah, yang secara luas juga merupakan sumber devisa Negara (Firmansyah D. Siregar, 2011). Lampung merupakan sebuah Provinsi yang paling selatan di Pulau Sumatera, disebelah utara berbatasan dengan Bengkulu dan Sumatera Selatan. Provinsi Lampung seluas 35.376,50 $\mathrm{km}^{2}$ terletak pada garis peta bumi : timurbarat diantara $105^{\circ} 45^{\prime}$ bujur barat serta $103^{0}$ $48^{\prime}$ bujur timur; utara-selatan diantara $3^{0}$ dan $45^{\prime}$ bujur utara dengan $6^{0}$ dan $45^{\prime}$ lintang selatan. Provinsi Lampung berada di sebelah barat berbatasan dengan selat sunda dan disebelah timur dengan laut jawa.

Provinsi Lampung merupakan salah satu provinsi yang telah ditetapkan sebagai daerah tujuan wisata (DTW) ke-18, sedangkan untuk Kota Bandar Lampung sesuai dengan kebijaksanaan yang ditempuh dalam bidang kepariwisataan menyediakan sarana dan prasarana pendukung mengingat kota Bandar Lampung merupakan ibukota Provinsi Lampung. Kota Bandar Lampung memiliki beberapa kawasan yang berpotensi (ditinjau dari perspektif kepariwisataan) untuk dikembangkan menjadi daerah objek tujuan wisata karena didukung topografi tinggi berbukit dan dataran rendah dekat dengan pantai yang diarahkan sebagai kawasan pendukung pariwisata.

Kota Bandar Lampung sebagai ibukota Provinsi Lampung memiliki berbagai objek wisata yang dapat dijadikan sebagai objek tujuan wisata yaitu pantai tirtayasa, pantai kubur, rumah adat Lampung, air terjun sukadanaham, taman hutan raya wan abdul rahman, taman wisata batu putu (Badan Pusat Statistik Kota Bandar Lampung, 2015). Namun di Bandar Lampung masih terdapat sebuah tempat pariwisata yang cukup berpotensi untuk ditingkatkan sebagai objek pariwisata unggulan yaitu hutan monyet lembah sarijo atau dikenal dengan taman monyet.

Dikawasan seluas sekitar 10 hektar ini hidup ratusan primata (monyet) yang bernama latin macaca fascicularis itu. Mereka hidup di hutan berdampingan dengan pemukiman warga dan hotel hartono. Areal konservasi primate (monyet) dan resapan air ini berada di perbatasan kelurahan sumur batu dan 
pahoman, teluk betung utara. Banyak orang menyebutnya hutan monyet lembah sarijo, sebab ia berada di wilyah yang biasa disebut sarijo. Hutan ini merupakan daerah resapan air, selain itu hutan monyet di daerah lembah sarijo ini memilliki potensi lain yaitu pemandian bidadari yang dipercaya warga sekitar dapat membuat awet muda bagi para pengunjung yang membasuh muka ditempat tersebut serta situs bersejarah berupa goa peninggalan sisa perjuangan pada jaman penjajahan melawan belanda. Lokasi hutan taman monyet itu sendiri berada di daerah pemerintahan kota Bandar Lampung yang tepatnya berada ditengah pusat kota Bandar Lampung, bagi pengunjung yang ingin datang ke hutan taman monyet bisa ditempuh melalui 2 jalur. Jalur yang pertama melewati Jl.cipto mangunkusumo dan tembusan ke Jl. Juanda. Daerah ini dikenal dengan nama tirtosari, sedangkan jalur ke dua melalui Jl. Dr. Susilo ke Jl.kesehatan (tepatnya depan kantor dinas kesehatan Provinsi Lampung).

Keberadaaan monyet yang ada di lembah sarijo ini tampak jinak kepada manusia sehingga pengunjung bisa dengan bebas memberi pisang kepada satwa yang dikenal dengan nama latin Macaca Fascicularis yang cukup terkenal hidup kelompok. Sekitar 250 ekor monyet ekor panjang hidup dikawasan lembah sarijo (www.lampung.tribunnews.com). Setiap pagi dan sore para monyet tersebut keluar dari hutan dan gua lalu menuruni lembah sarijo untuk mencari makanan di hutan sekitar hutan taman monyet serta di sekitar rumah warga. Untuk mempertahankan hidup, hewan-hewan ini memakan buah dan pucuk daun muda yang tumbuh dihutan itu.
Selain itu para monyet tersebut juga mengandalkan makanan pemberian warga yang tinggal di sekitar hutan serta pengunjung yang datang ke taman monyet ini. Hal itu disebabkan oleh pakan alami di habitat primata tersebut memang sedikit berkurang dikarenakan adanya areal pembangunan perumahan disekitar daerah lembah sarijo. Untuk itu diperlukan alokasi dana untuk memenuhi kebutuhan pangan monyet-monyet tersebut

(https://anakotah.blogspot.co.id/2016/12/tam an-wisata-hutan-kera.html).

Kurangnya perhatian pemerintah Provinsi Lampung dan dinas pariwisata kota Bandar Lampung serta kurang pedulinya masyarakat sekitar daerah hutan taman monyet inilah yang menyebabkan potensi-potensi yang dimiliki taman monyet tersebut menjadi kurang maksimal. Bahkan masyarakat khususnya yang berdomisili di kota Bandar Lampung kurang mengetahui tentang keberadaan hutan taman monyet dengan potensi-potensi yang ada di daerah tersebut. Taman monyet memang belum terkenal seperti tempat-tempat pariwisata lainnya yang berada di Provinsi Lampung. Namun, apabila dikelola dengan baik taman monyet dapat memberikan kontribusi besar baik masyarakat daerah hutan taman monyet dengan tumbuhnya ekonomi mikro dan berkurangnya tingkat pengangguran serta berdampak positif bagi pemerintah dengan berkontribusi dalam meningkatkan pendapatan daerah kota Bandar Lampung itu sendiri.

Pengembangan pariwisata merupakan suatu rangkaian upaya untuk mewujudkan keterpaduan dalam penggunaan berbagai sumber daya pariwisata mengintegrasikan 
segala bentuk aspek di luar pariwisata yang berkaitan secara langsung maupun tidak langsung akan kelangsungan pengembangan pariwisata. (Swarbrooke, 1996).

Mengingat begitu eratnya dengan berbagai bidang lain dalam proses pembangunan nasional maka aktifitas kepariwisataan bisa dikembangkan secara optimal sehingga pengembangan merupakan suatu proses pelaksanaan program yang terus meningkat ke arah puncak capaian sesuai dengan tujuan yang telah dicanangkan.
Asset adalah sumber daya ekonomi yang dikuasai dana atau dimiliki oleh pemerintah sebagai akibat dari peristiwa masa lalu dan dari mana manfaat ekonomi dan atau sosial di masa depan diharapkan dapat diperoleh, baik oleh pemerintah maupun masyarakat, serta dapat diukur dalam satuan uang, termasuk sumber daya nonkeuangan yang diperlukan untuk penyediaan jasa bagi masyarakat umum dan sumber-sumber daya yang dipelihara karena alasan sejarah dan budaya (Siregar, 2004).

\section{Variabel}

\begin{tabular}{|c|c|c|}
\hline Variabel & Konsep & Indikator \\
\hline $\begin{array}{l}\text { Konsep Pengembangan } \\
\text { Pariwisata }\left(\mathrm{X}_{1}\right)\end{array}$ & $\begin{array}{l}\text { Konsep pengembangan } \\
\text { pariwisata merupakan } \\
\text { suatu rangkaian upaya } \\
\text { untuk mewujudkan } \\
\text { keterpaduan dalam } \\
\text { penggunaan berbagai } \\
\text { sumber daya pariwisata } \\
\text { mengintegrasikan segala } \\
\text { bentuk aspek di luar } \\
\text { pariwisata yang berkaitan } \\
\text { secara langsung maupun } \\
\text { tidak langsung akan } \\
\text { kelangsungan } \\
\text { pengembangan } \\
\text { pariwisata (Swarbrooke, } \\
\text { 1996). }\end{array}$ & $\begin{array}{l}\text { 1. Membangun atraksi di situs yang } \\
\text { tadinya tidak digunakan sebagai } \\
\text { atraksi. } \\
\text { 2. Membangun atraksi pada situs } \\
\text { yang sebelumnya telah } \\
\text { digunakan sebagai atraksi. } \\
\text { 3. Atraksi yang dibangun untuk } \\
\text { menarik pengunjung lebih } \\
\text { banyak } \\
\text { 4. Atraksi dapat mencapai pasar } \\
\text { yang lebih luas, dengan meraih } \\
\text { pangsa pasar yang baru. } \\
\text { 5. Pengembangan baru pada } \\
\text { keberadaan atraksi } \\
\text { 6. Penciptaan kegiatan-kegiatan } \\
\text { baru }\end{array}$ \\
\hline
\end{tabular}

\begin{tabular}{|l|l|l|}
\hline \multicolumn{1}{|c|}{ Variabel } & \multicolumn{1}{|c|}{ Konsep } & \multicolumn{1}{c|}{ Indokator } \\
\hline Konsep Pengembangan & Konsep pengembangan & 7. Membangun atraksi di situs yang \\
Pariwisata $\left(\mathrm{X}_{1}\right)$ & pariwisata merupakan & tadinya tidak digunakan sebagai \\
& suatu rangkaian upaya & atraksi. \\
& untuk mewujudkan & 8. Membangun atraksi pada situs \\
& keterpaduan dalam & yang sebelumnya telah \\
\hline
\end{tabular}




\begin{tabular}{|c|c|c|}
\hline & $\begin{array}{l}\text { penggunaan berbagai } \\
\text { sumber daya pariwisata } \\
\text { mengintegrasikan segala } \\
\text { bentuk aspek di luar } \\
\text { pariwisata yang berkaitan } \\
\text { secara langsung maupun } \\
\text { tidak langsung akan } \\
\text { kelangsungan } \\
\text { pengembangan } \\
\text { pariwisata (Swarbrooke, } \\
\text { 1996). }\end{array}$ & $\begin{array}{l}\text { digunakan sebagai atraksi. } \\
\text { 9. Atraksi yang dibangun untuk } \\
\text { menarik pengunjung lebih } \\
\text { banyak } \\
\text { 10. Atraksi dapat mencapai } \\
\text { pasar yang lebih luas, dengan } \\
\text { meraih pangsa pasar yang baru. } \\
\text { 11. Pengembangan baru pada } \\
\text { keberadaan atraksi } \\
\text { 12. Penciptaan kegiatan- } \\
\text { kegiatan baru }\end{array}$ \\
\hline $\begin{array}{l}\text { Aspek - Aspek } \\
\text { Pengembangan Pariwisata } \\
\left(\mathrm{X}_{2}\right)\end{array}$ & $\begin{array}{l}\text { Menurut UU RI No. } 23 \\
\text { Tahun } 1997 \text { dalam } \\
\text { Marsongko (2001), } \\
\text { lilngkungan hidup adalah } \\
\text { kesatuan ruang dengan } \\
\text { semua benda, daya, } \\
\text { keadaan dan makhluk } \\
\text { hidup termasuk manusia } \\
\text { dan perilakunya, yang } \\
\text { mempengaruhi } \\
\text { kelangsungan peri- } \\
\text { kehidupan dan } \\
\text { kesejahteraan manusia } \\
\text { serta makhluk hidup } \\
\text { lainnya. }\end{array}$ & $\begin{array}{l}\text { 1. Aspek fisik } \\
\text { 2. Aspek Daya Tarik Pariwisata } \\
\text { 3. Aspek Aksesibilitas } \\
\text { 4. Aspek Aktivitas dan Fasilitas } \\
\text { 5. Aspek Sosial Ekonomi dan } \\
\text { Budaya }\end{array}$ \\
\hline $\begin{array}{l}\text { Upaya Pengembangan } \\
\text { Pariwisata }\left(\mathrm{Y}_{1}\right)\end{array}$ & $\begin{array}{l}\text { Pembukaan UUD } 1945 \\
\text { ada amanah yang } \\
\text { kiranya dapat dijadikan } \\
\text { capaian tujuan itu, yakni } \\
\text { terwujudnya } \\
\text { kesejahteraan umum, } \\
\text { mencerdaskan kehidupan } \\
\text { bangsa dan ikut } \\
\text { mewujudkan perdamain } \\
\text { dunia. Kata-kata kun ci } \\
\text { dari Pembukaan UUD } \\
\text { 1945 tersebut penting } \\
\text { dikemukakan agar }\end{array}$ & 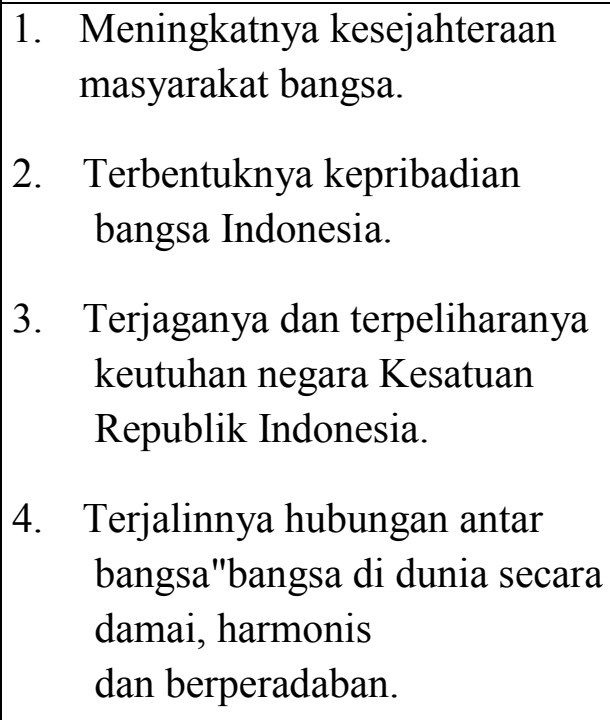 \\
\hline
\end{tabular}




\begin{tabular}{|c|c|c|}
\hline & industri pariwisata & $\begin{array}{l}\text { 5. Terbinanya kreatifitas } \\
\text { masyarakat bangsa dalam } \\
\text { berbagai segi kehidupan. } \\
\text { 6. } \begin{array}{l}\text { Terbangunnya keseimbangan } \\
\text { hidup masyarakat bangsa } \\
\text { dengan keberlangsungan } \\
\text { kehidupannya. }\end{array} \\
\text { 7. Terbangkitkannya spiritualitas } \\
\text { masyarakat bangsa. } \\
\text { 8. Terjalinnya kebersamaan dan } \\
\text { kepedulian untuk percepatan } \\
\text { optimalisasi sektor pariwisata. }\end{array}$ \\
\hline Asset Periwisata $\left(\mathrm{Y}_{2}\right)$ & $\begin{array}{l}\text { Asset adalah sumber } \\
\text { daya ekonomi yang } \\
\text { dikuasai dana atau } \\
\text { dimiliki oleh pemerintah } \\
\text { sebagai akibat dari } \\
\text { peristiwa masa lalu dan } \\
\text { dari mana manfaat } \\
\text { ekonomi dan atau sosial } \\
\text { di masa depan } \\
\text { diharapkan dapat } \\
\text { diperoleh, baik oleh } \\
\text { pemerintah maupun } \\
\text { masyarakat, serta dapat } \\
\text { diukur dalam satuan } \\
\text { uang, termasuk sumber } \\
\text { daya nonkeuangan yang } \\
\text { diperlukan untuk } \\
\text { penyediaan jasa bagi } \\
\text { masyarakat umum dan } \\
\text { sumber-sumber daya } \\
\text { yang dipelihara karena } \\
\text { alasan sejarah dan } \\
\text { budaya. }\end{array}$ & $\begin{array}{l}\text { 1. Pendapatan asli daerah } \\
\text { 2. Dana perimbangan } \\
\text { 3. Pinjaman daerah } \\
\text { 4. Pendapatan daerah yang asli lain } \\
\text { - lain }\end{array}$ \\
\hline
\end{tabular}




\section{Analisis Jalur}

Analisis jalur merupakan sebuah analisis yang menentukan besarnya hubungan kausal antar variabel baik pengaruh secara langsung maupun tidak langsung (sewall wright dalam ety rochaety,2009). Analisis jalur yang dipakai dalam penelitian ini adalah dua persamaan yaitu $X$ sebagai variabel eksdogen sedangkan variabel $\mathrm{Y}$ sebagai variabel endogen(Sugiyono,2006 dan Sudarmanto,2005). Persamaan strukturalnya dapat dilihat sebagai berikut: (David C. Rubin, 1997)

$$
\begin{aligned}
& \mathrm{X}_{2}= \mathrm{P}_{\mathrm{YX}} \mathrm{X}_{1}+\epsilon \\
& \quad(\text { persamaan jalur struktural 1) } \\
& \mathrm{Y}_{1}= \mathrm{P}_{\mathrm{YX}} \mathrm{X}_{1}+\epsilon_{1} \\
& \quad(\text { persamaan jalur struktural } 2) \\
& \mathrm{Y}_{1}= \mathrm{P}_{\mathrm{XY}} \mathrm{X}_{2}+\epsilon_{2} \\
& \quad(\text { persamaan jalur struktural } 3) \\
& \mathrm{Y}_{2}= \mathrm{P}_{\mathrm{YX}} \mathrm{Y}_{1}+\epsilon_{3} \\
& \quad(\text { persamaan jalur struktural 4) } \\
& \mathrm{Y}_{2}=\mathrm{P}_{\mathrm{YX}} \mathrm{X}_{1}+\mathrm{P}_{\mathrm{YX}} \mathrm{Y}_{1}+\epsilon_{4} \\
& \quad(\text { persamaan jalur struktural 5) } \\
& \mathrm{Y}_{2}=\mathrm{P}_{\mathrm{YX}} \mathrm{X}_{2}+\mathrm{P}_{\mathrm{YX}} \mathrm{Y}_{1}+\epsilon_{4} \\
& \quad(\text { persamaan jalur struktural 6) } \\
& \mathrm{Z}=\quad \mathrm{P}_{\mathrm{YX}} \mathrm{X}_{1}+\mathrm{P}_{\mathrm{YX}} \mathrm{X} 2+\mathrm{P}_{\mathrm{YX}} \mathrm{Y} 1+\epsilon_{4} \\
& \quad(\text { persamaan jalur struktural 7) }
\end{aligned}
$$

\section{Hasil}

Hipotesis 1, 4, 5, 6 dan 7 adalah $\mathrm{H}_{\mathrm{o}}$ diterima artinya semua tidak mempunyai pengaruh signifikan, sedangkan untuk hipotesis 2 dan 3 adalah $\mathrm{H}_{\mathrm{a}}$ diterima artinya semua ada pengaruh signifikan. Hasil koefisien determinasi $\mathrm{R}$ Square sebesar 0,014 atau $14 \%$, hal ini menunjukkan bahwa bahwa variabel aspek-aspek pengembangan pariwisata $\left(\mathrm{X}_{2}\right)$ dipengaruhi oleh variabel konsep pengembangan pariwisata dengan $\left(\mathrm{X}_{1}\right)$ dengan nilai persentase yang diperoleh sebesar $1,4 \%$ sedangkan sisanya sebesar 98,6\% dipengaruhi oleh faktor lain selain variabel konsep pengembangan pariwisata $\left(\mathrm{X}_{1}\right)$. Hasil $\mathrm{R}$ Square sebesar 0,194 atau $19,4 \%$ hal ini menunjukkan bahwa variabel upaya pengembangan pariwisata $\left(\mathrm{Y}_{1}\right)$ dipengaruhi oleh variabel konsep pengembangan pariwisata dengan $\left(\mathrm{X}_{1}\right)$ dengan nilai persentase yang diperoleh sebesar 19,4\% sedangkan sisanya sebesar $81,6 \%$ dipengaruhi oleh faktor lain selain variabel upaya pengembangan pariwisata $\left(\mathrm{Y}_{1}\right)$, hasil $\mathrm{R}$ Square sebesar 0,032 atau 3,2\% menunjukkan bahwa variabel upaya pengembangan pariwisata $\left(\mathrm{Y}_{1}\right)$ dipengaruhi oleh variabel aspek-aspek pengembangan pariwisata dengan $\left(\mathrm{X}_{2}\right)$ dengan nilai persentase yang diperoleh sebesar 3,2\% sedangkan sisanya sebesar $96,8 \%$ dipengaruhi oleh faktor lain selain variabel aspek-aspek pengembangan pariwisata $\left(\mathrm{X}_{2}\right)$. Hasil R Square 0,038 atau 3,8\% hal ini menunjukkan bahwa variabel konsep pengembangan pariwisata $\left(\mathrm{X}_{1}\right)$ melalui upaya pengembangan pariwisata $\left(\mathrm{Y}_{1}\right)$ dipengaruhi oleh variabel konsep pengembangan pariwisata dengan $\left(\mathrm{X}_{1}\right)$ dengan nilai persentase yang diperoleh sebesar 3,8\% sedangkan sisanya sebesar $96,2 \%$ dipengaruhi oleh faktor lain selain variabel konsep pengembangan pariwisata $\left(\mathrm{X}_{1}\right)$ dan upaya pengembangan pariwisata (Y). Hasil R Square 0,549 atau 54,9\% hal ini menunjukkan bahwa variabel asset pemerintah Bandar Lampung $\left(\mathrm{Y}_{2}\right)$ dipengaruhi oleh variabel konsep pengembangan pariwisata dengan $\left(\mathrm{X}_{2}\right)$ dan upaya pengembangan pariwisata $\left(\mathrm{Y}_{1}\right)$ dengan nilai persentase yang diperoleh 
sebesar 54,9\% sedangkan sisanya sebesar $36,1 \%$ dipengaruhi oleh faktor lain selain variabel aspek-aspek pengembangan pariwisata $\left(\mathrm{X}_{2}\right)$ dan upaya pengembangan pariwisata $\left(\mathrm{Y}_{1}\right)$. R Square 0,194 atau 19,4\% artinya variabel asset pemerintah $\left(\mathrm{Y}_{2}\right)$ dipengaruhi oleh variabel upaya pengembangan pariwisata dengan $\left(\mathrm{Y}_{1}\right)$ dengan nilai persentase yang diperoleh sebesar 19,4\% sedangkan sisanya sebesar $81,6 \%$ dipengaruhi oleh faktor lain selain variabel upaya pengembangan pariwisata $\left(\mathrm{Y}_{1}\right)$. Hasil $\mathrm{R}$ Square sebesar 0,551 atau $55,1 \%$ artinya variabel asset pemerintah $\left(\mathrm{Y}_{2}\right)$ dipengaruhi oleh variabel konsep pengembangan pariwisata dengan $\left(\mathrm{X}_{1}\right)$ dan aspek-aspek pengembangan pariwisata $\left(\mathrm{X}_{2}\right)$ dengan nilai persentase yang diperoleh sebesar 55,1\% sedangkan sisanya sebesar $44,9 \%$ dipengaruhi oleh faktor lain selain variabel konsep pengembangan pariwisata $\left(\mathrm{X}_{1}\right)$ dan aspek-aspek pengembangan pariwisata $\left(\mathrm{Y}_{2}\right)$.

\section{DAFTAR PUSTAKA}

[1] Badan Pusat Statistik Kota Bandar Lampung. 2015. Bandar Lampung dalam Angka Tahun 2015 Bandar Lampung; BPS Kota Bandar Lampung

[2] David C. Rubin, 1997, Statistics for management, Oxford university press.

[3] Ety Rochaety,2009, "Metodologi Penelitian Bisnis, Jakarta, Mitra Wacana Media.

[4] Kotler, P., 1997, Marketing Management Analysis, Planning, Implementation, and Control, new jersey: Prentice hall International Inc

[5]Nazir, M., 2003, Metode Penelitian,Jakarta,Ghalia Indonesia.

6] MB-IPB 2010, Ekowisata Kebun Raya Cibodas,Manajemen dan Bisnis Institut Pertanian Bogor

[7] Sugiyono, 2006, Metode penelitian Bisnis, Alfabeta C. bandung.

[8] Sudarmanto, R., G., 2005, Analisis Regresi Linier Ganda, Edisi Pertama, Yogyakarta, Graha Ilmu.

[9] Swarbrooke, John, 1996, "Development and Management Of Visitor Attractions", Oxford, Butterworth-Heinemann.

[10] Siregar D, Doli (2004), Manajemen Aset, Jakarta : PT. Gramedia Pustaka Utama

[11]www.lampung.tribunnews.com/2013/09 26/asal-usul-kera-di-taman-hutankera-sumur-batu-bandar-lampung

[12]https://anakotah.blogspot.co.id/2016/12/ taman-wisata-hutan-kera.html 